\title{
COSOVAN Attila
}

\section{$\mathrm{VY}$}

Két dologról fogok mesélni; néhol párhuzamos, másutt pedig kereszteződő ritmusban:

- a designkommunikációról, azaz a DIS.CO-féle szemléletről és arról, hogy miben különbözik a designgondolkodástól, azaz a DESIGN THINKING-től, és röviden

- a ,VY" VEZETÉSTUDOMÁNY új ikonjának és címlapjának megtervezéséről.

\section{A designkommunikáció fogalma}

A védjegyoltalom alatt álló designkommunikáció tervezői/alkotói szemlélet, filozófia és módszer (teória és praxis), amely a következőképpen értendő: Designkommunikáció $=$ fejlesztésbe (fejlődésbe) integrált kommunikáció (ez egy lokális know-how globális hatásfokkal).

A DESIGN; tervezőmüvészet, kreatív tervezés, alkotói magatartás. Ehhez társul a KOMMUNIKÁCIÓ; a tervezöi, alkotói, kreatív kapcsolatteremtés, úgy az önreflexió (belső párbeszéd), mint az interhumánus fenomén szintjén. Így tehát a designkommunikáció egy olyan kapcsolatteremtési szemléletet képvisel, amely HÍD-ként jelenik meg a különböző diszciplínák és diskurzusok, a társadalom és a gazdaság jelenségei között. Inter-, transzdiszciplináris és interprofesszionális módszerével valós idejü kapcsolatot lehet teremteni oktatás, kutatás és vállalkozás között (Cosovan Horváth, 2016).

\section{A designkommunikáció alapvetései}

A kreatív üzenet vagy kapcsolatteremtés nem egy utólagos sallang, hanem a problémaészleléssel, -feltárással, -megoldással együtt születik és kódolódik a termék, szolgáltatás vagy éppen eljárás fejlődésébe. A tervezés, az alkotás és az ebből fakadó kapcsolatteremtési szándék az emberi faj egyik legfontosabb adottsága, lehetősége, kötelessége és egyben felelössége - figyelembe véve a társadalmi állandó(k) és változó(k) kölcsönhatását (Cosovan, 2015).
Az alkotói, tervezői kapcsolatteremtési képességünk, fajunk létezése óta determinálja integrált és differenciált, azaz komplex emberi entitásunkat, amely a minimum és maximum szabályokat figyelembe véve - a megismerés fenomenológiájában (anyag-anyagtalan viszonya, túlélés-fennmaradás-fejlödés viszonya, állandó-változó( $k$ ) viszonya) - egy holisztikus viszonyrendszerben fogalmazódik meg, ezzel segítve a tervezői, alkotói optimum megtalálását.

A designgondolkodás (design thinking, Brown, 2008) jellegü társadalmi manifesztációhoz képest a designkommunikáció kilép a tervezői gondolkodás kereteiből, melynek proaktív módszertana és szemlélete többek mellett a Csíkszentmihályi-féle áramlat (flow-élmény, Csíkszentmihályi, 2001), a Viktor E. Frankl-féle értelem-, értékközpontú egzisztenciaanalízis és a szókratészi párbeszéd bölcseletére épít (Sárkány, 2012).

Konklúzió: az állandó és változók együtthatója az alkotás, a kreativitás pedig a túlélési ösztön emberi és emocionális manifesżtációja.

\section{A VEZETÉSTUDOMÁNY (VY) új ikonja (logója, jele, szimbóluma)}

A V és az Y két olyan betü (absztrakt jel), amely ezt az összetett szót közrezárja, ráadásul mindkét betü képileg illusztrálja magát a szó jelentését. A VEZETÖI és a TUDOMÁNYOS világ vizuálisan értelmezhető esszenciáját képviseli. Az iránymutató háromszögek (VY) kiegészítéseként a háttérben megjelennek ezek „ellen” súlypontjai, amely a mai kortárs, együttmüködő, mellérendelt, elszámoltatható, fenntartható és egyensúlyra törekvő vezetői kultúrát szimbolizálja. A középre tartó „,V" betű a vezetői döntés felelősségének és lehetőségének kérdésfelvetését analizálja, az arany középút állandóságát sugallja stb.

$\mathrm{Az}$, ,Y” a választható döntésekről és lehetőségekröl, a szabad akaratról szól, az út mely elér valahova, de aztán szétágazva folytatódik...

Vizsgáljuk meg tervezői/alkotói szempontból (tartalmát tekintve design thinking és designkommunikációs szempontból egyaránt). 


\section{VEZETÉSTUDOMÁNY}

A design thinking módszertana elsősorban arra fókuszál, hogy mit akarunk elérni és azt hogyan tudjuk a legkreatívabban megtenni. Cél- és sikerorientált. Mivel alapvetően az emberi gondolkodás lehetőségének paradigmájára épít, ezért egy nagyon fontos állapotot figyelmen kívül hagy: általában nem figyel, nem számol - vagy inkább csak nem GONDOL - azokra a nyugvóponton lévő kapcsolatteremtési jellemzőkkel bíró elemekre, információkra és kódokra, amelyek az észlelés második, harmadik vagy még mélyebb rétegeiben helyezkednek el. A gondolkodás racionalizál, a kommunikáció érzékenyit - képessé tesz a gondolkodás nélküli kapcsolatteremtésre is ${ }^{1}$ - ez kritikus szituációkban néha életmentő is lehet.

Hogy jobban megértsük: a GONDOLKODÁS kifejezetten emberi jellemző, a KOMMUNIKÁCIÓ pedig univerzális, emberen túlmutató jelenség (Buda, 1986). Például ha az egysejtűekröl elmélkedünk; ott ugye nem beszélhetünk gondolkodásról?!? Kommunikációról viszont igen. De ha továbbmegyünk és az univerzum többi alkotóelemét vizsgáljuk, akár az élettelen közeget is; ott ugye szintén nem beszélhetünk gondolkodásról?!? És kommunikációról? Arról, talán igen! A fizikai állandók is leírhatóak a kommunikáció tulajdonságaival.

Nyilván a felvetésemmel nem rokonszenvezők, most azt is mondhatják; hogy eme diskurzus is csupán azért lehetséges, mert képesek vagyunk gondolkodni - de én inkább megfordítom. Azért vagyunk képesek gondolkodni, mert egy holisztikus univerzális állandó kommunikáció (kapcsolatteremtés) eredménye maga a gondolkodás is.

\section{A kreativitás a túlélési ösztön, emberi és emocionális manifesztációja.}

A VEZETÉSTUDOMÁNY szóban rejlő kreatív kapcsolatteremtési (designkommunikációs) lehetőség, mélyebb fogódzkodói túlmutatnak az összetett szó tartalmi értelmezésén átcsapva egy szemlélődő, érzékenyítö felfedezésbe, mely párosul a tabula rasa fenomenológiájával és így képes észrevenni olyan kódokat is, amelyek NEM VELETLENÜL bújnak meg a tudat, tudatalatti és a tudattalan mezsgyéjén.

Ezekből a rejtettnek tűnő kódokból él a designkommunikáció és talán emiatt lehet érdekes tudományfilozófiai szempontból hermeneutikai elemzése.

Visszatérve a JELÜNKHÖZ; hiszem, hogy a „V" és az „Y" betük, háttér-információja és vizuális kódja nem véletlenül tartalmazza mindazt, amit a VEZE-
TÉSTUDOMÁNY primer filozófiai értelmezése is megkíván. A különbség, abban van, hogy a mélyebb rétegekből felhozott kódok, sokkal értékesebbek az állandó-változó tengelyén; magyarul hosszú távú perspektívákat (túlélést-fennmaradást-fejlődést) predesztinálnak az ilyen típusú megoldások.

\section{A fedélterv további elemei közül a cikkek címei között} húzódó szaggatott vonalakról egy mondat:

Az inter- és transzdiszciplinarítás, valamint a wikinómikus ${ }^{2}$ (teljes) együttmüködés korában (Tapscott, 2007), ahol a határok átjárhatóak, ahol képesek vagyunk egymástól tanulni, ahol a fejlődés néha exponenciálisan történik, ott szükségünk lehet a szuverén saját identitásunk mellett egy globális, együttmüködni képes identitásra is; a szaggatott vonalak bátran, de azért kellő körültekintéssel átléphetők.

\section{Jegyzetek}

${ }^{1}$ Kapcsolatteremtés bármivel; élö és élettelen entitással egyaránt.

${ }^{2}$ https://hu.wikipedia.org/wiki/Wikin\%C3\%B3mia

\section{Felhasznált irodalom}

Brown, T. (2008): Design thinking. Harvard Business Review, 86(6), 84-93. o.

Buda B. (1986): A közvetlen emberi kommunikáció szabályszerüségei. Harmadik, bővített kiadás, Budapest: Animula

Cosovan A. (2015): A közhely fenntartható identitása. in: German K. (szerk): Sustainable Identities Fenntartható identitások. Velencei Biennálé Nemzeti Biztosi Iroda, Ludwig Múzeum, Budapest, 94-99. o.

Cosovan, A. - Horváth, D. (2016): Emóció-Ráció: Tervezés-Vezetés: Designkommunikáció. Vezetéstudomány/Budapest Management Review, 47(3), 36-45. o.

Csikszentmihályi, M. (2001). Flow-Az áramlat, a tökéletes élmény pszichológiája. Budapest: Akadémiai Kiadó

Sárkány P. (2012): Értelemközpontú egzisztenciaanalízis és filozófiai tanácsadás Viktor Frank1 halálának 15. évfordulójára. Imágó Budapest, 3, 75-82. o.

Tapscott, D. (2007): Wikinómia. Hogyan változtat meg mindent a tömeges együttmúködés? Budapest: HVG Kiadó 